\title{
MicroRNAs, cancer and ionizing radiation: Where are we?
}

\author{
Gustavo Nader Marta ${ }^{1 *}$, Bernardo Garicochea ${ }^{2}$, André Lopes Carvalho ${ }^{3}$, Julana M. Real ${ }^{4}$, Luiz Paulo Kowalski ${ }^{5}$ \\ ${ }^{1}$ M.D. - Physician at the Radiotherapy Service of the Hospital Sírio-Libanês, Physician of the Radiotherapy Service at the Instituto do Câncer do Estado de São Paulo (Icesp), São Paulo, SP, Brazil \\ ${ }^{2} \mathrm{PhD}$ - Physician at the Clinical Oncology Service, Hospital Sírio-Libanês, São Paulo, SP, Brazil \\ ${ }^{3} \mathrm{PhD}$ - Physician at the Head and Neck Surgery Division, Hospital de Câncer de Barretos - Fundacão Piu XII, Barretos, SP, Brazil \\ ${ }^{4} \mathrm{PhD}$ - Researcher at the Instituto Sírio-Libanês de Ensino e Pesquisa, São Paulo, SP, Brazil \\ ${ }^{5} \mathrm{PhD}$ - Head of the Head and Neck Surgery, and Otorhinolaryngology Division, A.C. Camargo Cancer Center, São Paulo, SP, Brazi
}

Study conducted at the Hospital Sírio-Libanês, Radiotherapy Service, São Paulo, SP, Brazil

Article received: $8 / 18 / 2014$ Accepted for publication: 8/24/2014

*Correspondence: Address: Rua Dona Adma Jafet, 91 São Paulo, SP - Brazil Postal code: 01308-050 gmarta@uol.com.br

http://dx.doi.org/10.1590/1806-9282.61.03.275 Conflict of interest: none

\section{SUMmaRY}

The aim of this study is to describe the biogenesis of microRNA, its relations with carcinogenesis, and the correlation between microRNA and ionizing radiation (IR), focusing on radioresponsiveness. It is known that microRNA biogenesis is well established and involves different enzymatic cleavages, resulting in the production of mature microRNA. MicroRNAs are involved in carcinogenesis. Their interaction is related to the genetic and epigenetic changes associated with activation of proto-oncogenes or inactivation of tumor suppressor genes. Several studies have shown that the levels of expression of some microRNAs vary significantly after irradiation. There are evidences that microRNAs can influence cellular response after IR. In addition, microRNAs are related to modulation of the expression of several post-transcriptional targets in DNA damage response pathways, and to the DNA damage repair regulation mechanism. Future studies can clarify a possible clinical use of microRNAs as a new class of radiosensitive agents.

Keywords: microRNAs, radiotherapy, neoplasms.

\section{INTRODUCTION}

MicroRNAs (miRNA, miR) are a class of endogenous small (16 to 22 nucleotides) non-coding RNAs that control the degradation and translation of target mRNAs and regulate almost $30 \%$ of human genes. ${ }^{1}$ MicroRNA genes have been normally found in cancer-related genomic areas. ${ }^{2}$ They can have diverse roles, such as acting as tumor suppressors or oncogenes depending on tissue type and the specific targets. ${ }^{3}$

The capacity of microRNAs to perform as regulators for gene expression permits them to influence signaling pathways that might modify several cellular processes, involved in irradiation response.

Ionizing radiations (IR) exert their effects through both direct and indirect actions. Direct action means direct injury to the DNA, while indirect action is umpired through free radicals created through ionization of $\mathrm{H}_{2} \mathrm{O}$. Therefore, DNA damage might appear in different forms such as single-strand breaks (repaired via base excision repair) and double-strand breaks (DSBs), repaired via homologous recombination repair, which is accurate, or non homologous end-joining, which is error-prone. Whereas several cells suffer apoptosis after
IR, cell death also can be related to IR-induced injury that triggers cell inactivation and becomes lethal after some cell divisions. ${ }^{4}$

The DNA injury response pathways have an important role in defining cell survival, radiosensitivity and cell cycle checkpoints. Cellular sensitivity to IR is commonly determined by DNA DSB repair. However, it is important to know other issues that could be associated with IR, and their effects on tissues: microRNAs as inherent gene regulators may offer new likelihoods in this context.

The aim of this study was to review the microRNA biogenesis, carcinogenesis actions, and the most recent evidences of microRNA and IR regarding radiosensitivity response.

\section{RESULTS}

MicroRNA: biogenesis

MicroRNAs are found in most eukaryotes and their biogenesis involves several enzymatic cleavages that result in the production of mature microRNA. ${ }^{5}$

RNA polymerase II transcribes microRNA genes and creates primiRNAs (primary microRNA transcripts). ${ }^{6} \mathrm{Af}-$ 
ter enzymatic action and the removal of introns, the resulting RNA shows the changes in the usual 5' (cap) and 3' (insertion of adenine tail) sequences forming a molecule with thousands of bases (pri-microRNAs). A pri-microRNA is cleaved by complex formed by the RNase III Drosha and its cofactor DGCR8 (DiGeorge syndrome critical region in gene 8) to create a hairpin structured forerunner, or premicroRNA with 70-100 nucleotides in the nucleus. Pre-microRNAs are brought to the cytoplasm via nuclear receptor-dependent exportin-5 RanGTP. ${ }^{7,8}$

In the cytoplasm, pre-microRNA is cleaved by Dicer (RNase) to create a microRNA duplex intermediate 22 base pairs. In this process, the Dicer interacts with the protein TRBP (trans-activation response RNA-binding protein) kinase and PRKRA/PACT (interferon-inducible double stranded RNA-dependent activator). ${ }^{9}{ }^{910}$ An Argonaute (Ago) protein binds the duplex and integrates the mature, single-stranded microRNA into the Ago:RNA complex to produce mature RNA-induced silencing complex (RISC), whilst the other strand is often rejected. ${ }^{11-13}$

\section{MicroRNA and carcinogenesis}

There are two major mechanisms used in gene expression regulation by repression and degradation of the mRNA translation target (RISC). This interaction is related to the complementary bases intensity between mRNA and microRNA. ${ }^{14,15}$

MicroRNAs are involved in the carcinogenesis process. Their interaction is related to genetic changes associated with the activation of proto-oncogenes or inactivation of tumor suppressor genes. Thus, microRNAs can be grouped into two categories: oncomicroRNAs (negatively regulate tumor suppressor genes), and anti-oncomicroRNA (act in the negative regulation of oncogenes). ${ }^{16,17}$ However, a single microRNA can exert both actions, depending on their performance in the target tissue. ${ }^{18}$

The relationship of microRNAs in tumorigenesis was first described in chronic lymphocytic leukemia (microRNA-15 and microRNA-16). ${ }^{19}$ Subsequently, microRNAs modification was shown in several neoplasms, such as breast cancer, lymphoma, lung, head and neck, colorectal, prostate, liver, pancreas and thyroid. ${ }^{20}$ As an example, the family of microRNAs let-7 regulates some oncogenes (HmgA2, Myc, and Ras) and they are poorly expressed in lung, prostate, glioblastoma. In addition, its low expression correlates with a worse prognosis in patients with lung cancer. ${ }^{21-23}$ Conversely, the microRNA 17-92 clusters can also act as oncogene and they are overexpressed in some types of lung and kidney cancers..$^{24,25}$
MicroRNAs are normally located in genome areas related to alterations in cancer. ${ }^{26,27}$ Mutations could be observed in the primary transcripts of microRNA-15a and microRNA-6-1, involved in reducing expression of the two microRNAs in leukemia. ${ }^{28}$

Moreover, deregulated microRNA expression may be associated with epigenetic alterations, such as changed DNA methylation. It was suggested that microRNA-34b/c and B-cell translocation gene 4 (BTG4) are novel tumor suppressors in colorectal cancer and that the microRNA$34 \mathrm{~b} / \mathrm{c} \mathrm{CPG}$ island, which bidirectionally regulates microRNA-34b/c and BTG4, is a common target of epigenetic silencing in colorectal cancer. ${ }^{29}$

Likewise, another epigenetic system can disturb microRNAs expression: histone acetylation. Histone deacetylase inhibition is followed by the vast and rapid modification of microRNA levels. ${ }^{30}$ For example, in breast carcinoma cell lines, Rhodes et al. ${ }^{31}$ using histone deacetylase inhibitor (HDACi) trichostatin A (TSA) demonstrated the suppression of in vitro clonogenicity in the previously described apoptosis resistance. Significant upregulation of 22 microRNAs and downregulation of 10 microRNAs in response to TSA treatment was observed. These results demonstrate that HDACi TSA exerts anticancer activity in apoptosis resistance. This activity is correlated with TSA alteration of microRNA expression profiles indicative of a less aggressive phenotype.

Another important point is that microRNA expression may be modulated as a result of deregulations in the microRNA biogenesis. ${ }^{32}$ It was demonstrated that Dicer silencing promotes cellular transformation and tumorigenesis in vivo. Kumar et al. ${ }^{33}$ analyzed the consequences of conditional Dicer1 mutation (Dicer1 "floxed" or Dicer1(fl)) on several mouse models of cancer. Deletion of a single copy of Dicer1 in tumors from Dicer1(fl) animals led to reduced survival compared with controls. Tumors from Dicer1(fl/fl) animals always maintained one functional Dicer1 allele. Consistent with selection against full loss of Dicer1 expression, enforced Dicer1 deletion caused inhibition of tumorigenesis. These findings suggest that Dicer1 may be an important haploinsufficient tumor-suppressor gene. Moreover, there are some evidences suggesting that loss of Dicer and/or Drosha has been inversely related with outcome in different types of tumors. ${ }^{3437}$

MicroRNA processing can also be affected directly or indirectly by other microRNAs producing a complex reciprocal relationship. MicroRNA family, microRNA-103/107, was identified. This family attenuates microRNA biosynthesis by targeting Dicer. In human breast cancer, high lev- 
els of microRNA-103/107 are associated with metastasis and poor outcome. Functionally, microRNA-103/107 award migratory capacities in vitro and empower metastatic dissemination of otherwise non aggressive cells in vivo. Inhibition of microRNA-103/107 opposes migration and metastasis of malignant cells. At cellular level, a key event fostered by microRNA-103/107 is induction of epithelial-to-mesenchymal transition attained by downregulating microRNA-200 levels. ${ }^{38}$

Finally, changes in microRNA expression can be a consequence of transcription variations due to an altered transcription factor action. MicroRNA can be either negatively or positively regulated by $\mathrm{p} 53,{ }^{39} \mathrm{MYC},{ }^{40}$ or ZEB1 $1{ }^{41}$

Thus, there are many uncertainties about the mechanisms involved in microRNAs expression and tumors. Nonetheless, they are probably alike to those that affect the expression of genes, encoding proteins, such as DNA mutations (deletions, substitutions, insertions, translocations and amplifications) and epigenetic alterations. ${ }^{42}$ Furthermore, there is evidence that microRNAs in cancers may be deregulated and there are derangements and transcriptional defects in their biogenesis. ${ }^{43}$

\section{MicroRNA changes after IR}

The roles of specific microRNAs in IR response have only recently begun to be observed. Several studies have demonstrated that the expression levels of some microRNAs change notably after irradiation. This fact was confirmed in different cell types and at variable irradiation doses (Xray or gamma ray). Table 1 summarizes the levels of microRNA expression after IR in some cell lines.

MicroRNAs can be directly involved in apoptosis regulation and cell cycle. It was shown that let-7 cluster of microRNA is associated with cellular differentiation and proliferation and likewise acts as a tumor suppressor. ${ }^{44}$ Kras is one of the recognized targets of the let- 7 family; ${ }^{45}$ RAS amplified seems to protect tissues from IR and sponsor growth, ${ }^{46}$ demonstrating that there may be a positive relationship between the radiation response and let-7. As it can be observed in Table 1, IR changed let7 cluster expression in different cell lines: they are downregulated or upregulated, showing discrepancies among the results. Additional studies are required to establish the main reason for the divergence between current reporting papers and whether other mechanisms are involved.

Simone et al. ${ }^{47}$ have studied the alterations in microRNA expression in primary human fibroblasts following exposure to several stress-inducing anticancer agents including IR, etoposide and hydrogen peroxide $\left(\mathrm{H}_{2} \mathrm{O}_{2}\right)$ to observe the biological consequences. Changes in microRNA expression were observed for 17 microRNA species, following exposure to radiation, 23, after $\mathrm{H}_{2} \mathrm{O}_{2}$, and 45 , after etoposide; seven microRNA species were commonly altered by all the agents. These results demonstrate a common microRNA expression signature in response to exogenous genotoxic agents. Furthermore, pre-treatment with cysteine prevented radiation-induced alterations in microRNA expression, which suggests that microRNAs are responsive to oxidative stress. It could be implied that microRNAs play a role in cellular defense against exogenous stress and are involved in the generalized cellular response to genotoxic oxidative stress.

Some microRNAs were associated with essential protective mechanisms counteracting radiation cytotoxicity. MicroRNA-34 was found to be a straight target for $\mathrm{p} 53$, functioning downstream of the $\mathrm{p} 53$ pathway as a tumor suppressor. MicroRNA-34 targets Notch, HmgA2 and $\mathrm{Bcl}-2$ genes involved in self-renewal and survival of tumor cells. ${ }^{48}$ IR led to an important increase in the expression of microRNA-34a, equaled by a decline in the expression of its target oncogenes NOTCH1, MYC, E2F3, and cyclin D1.

A pivotal regulator of DNA methylation and genome stability, lymphoid specific helicase (LSH), was associated to microRNA-7. After IR, LSH was upregulated, while microRNA-7 was downregulated. Koturbash et al. ${ }^{49}$ have analyzed the effects of X-ray irradiation on microRNA expression in the hippocampus, frontal cortex, and cerebellum of male and female mice. It was shown that changes in the expression of the microRNA-29 family could be related to altered expression of de novo methyltransferase DNMT3a and changed global DNA methylation levels. Taken together, this seems to be a cellular protective effect against radiation-induced hypomethylation. ${ }^{50}$

Additional authors have assessed the influence of microRNA and cells reaction after irradiation. Kraemer et al..$^{51}$ reported the functional role results of microRNAs in radiation response in immortalized and primary endothelial cells. Overall suppression of microRNA expression was accomplished through downregulation of Dicer or Ago2. The decreases in those components led to improved cell death after irradiation, denoting a prosurvival role of microRNAs. Moreover, whilst cell cycle checkpoint activation and apoptosis were impaired, the low microRNAs levels did not disturb DNA DSB repair. The distinctive sensitivity of these pathways suggests the autonomous activation of the two response pathways rather than a repaired DNA damage response. Nevertheless, Surova et al., ${ }^{52}$ 
TABLE 1 MicroRNAs levels of expression after IR.

\begin{tabular}{|c|c|c|}
\hline Cell type & Increase & Decrease \\
\hline \multicolumn{3}{|l|}{ Central nervous system } \\
\hline Glioma $^{31,32,33}$ & $\begin{array}{l}\text { let-7a; let-7b; let-7c; let-7d; let-7e; let-7f; let-7g; let-7i; miR-15a; } \\
\text { miR-16; miR-17-3p; miR-17-5p; miR-19a; miR-19b; miR-22; } \\
\text { miR-21; miR-142-3p; miR-142-5p; miR-143; miR-155; miR-191; } \\
\text { miR-379; miR-601 }\end{array}$ & miR-107; miR-181a; miR-521 \\
\hline $\begin{array}{l}\text { Mouse hippocampal cells and } \\
\text { brain tissue }^{34}\end{array}$ & miR-21 & - \\
\hline \multicolumn{3}{|l|}{ Head and neck } \\
\hline Thyroid 35,36 & $\begin{array}{l}\text { let-7c; let-7d; let-7g; miR-17-3p; miR-17-5p; miR-27b; miR-34a; } \\
\text { miR-34b; miR-188-5p; miR-365 }\end{array}$ & let-7f; let-7g; miR-10a; miR-106a; miR-152 \\
\hline \multicolumn{3}{|l|}{ Thorax } \\
\hline $\begin{array}{l}\text { Lung cancer and normal } \\
\text { epithelial cell line } \text { li,38,39 }^{37}\end{array}$ & $\begin{array}{l}\text { miR-15a; miR-16; miR-17-5p; miR-19a; miR-19b; miR-20b; } \\
\text { miR-22; miR-24; miR-27a; miR-27b; miR-30a-5p; miR-99a; } \\
\text { miR-106a; miR-148a; miR-221; miR-365; miR-126; let-7a; } \\
\text { miR-495; miR-451; miR-128b }\end{array}$ & $\begin{array}{l}\text { let-7a; let-7b; let-7c; let-7d; let-7e; let-7f; } \\
\text { let-7i; miR-26b; miR-125a; miR-155; } \\
\text { miR 130a, miR-106b, miR-19b, miR-22, } \\
\text { iR-15b, miR-17-5p; miR-21 }\end{array}$ \\
\hline \multicolumn{3}{|l|}{ Genitourinary } \\
\hline Prostate $^{40,41,42}$ & $\begin{array}{l}\text { miR-191; miR-379; miR-29b 7; miR-191; miR-22; miR-200c; } \\
\text { miR-141; miR-24; miR-30a-5p; miR-9-1 }\end{array}$ & $\begin{array}{l}\text { miR-100; miR-107; miR-133b; miR-143; } \\
\text { miR-145; miR-196a; miR-521; miR-106b; } \\
\text { miR-199a }\end{array}$ \\
\hline
\end{tabular}

\section{Gastrointestinal}

Rectum $^{43,44}$

miR-1183; miR-483-5p; miR-622; miR-125a-3p; miR-1224-5p; miR-1274b; miR-720

miR-188-5p; miR-1471; miR-671-5p; miR-1909; miR-630;

miR-765; miR125b; miR137

\section{Hematology}

Non-Hodgkin lymphoma ${ }^{45}$

miR-1913; miR-Plus-F1147; miR-148b; miR-589; miR-106b; miR-29a; miR-335; miR-193b; miR-21; miR-Plus-G1246-3p; miR-19b; miR-1280; miR-BHRF1-1; miR-340; miR-33a; let-7e; miR-Plus-E1098; miR-20a miR-483-3p; miR-200b

\section{Breast}

Breast $^{46}$

miR-302a; miR-302b; miR-302c; miR-302d; miR-302e

\section{Other}

Normal human fibroblasts ${ }^{47}$

let-7d; let-7e; let-7f; let-7g; let-7i; miR-15a; miR-17-3p; miR-17-5p; let-7a; let-7b; let-7d; miR-24; miR-155; miR-19b; miR-21; miR-26b; miR-142-3p; miR-142-5p; miR-143; miR-222

miR-145; miR-155; miR-663

\begin{tabular}{lll}
\hline $\begin{array}{l}\text { Human 3-D airway model } \\
\text { tissues }^{48}\end{array}$ & - & $\begin{array}{l}\text { let-7a; let-7b; let-7c; let-7d; let-7e; let-7f; } \\
\text { let-7g; let-7i }\end{array}$ \\
\hline Lymphocytes $^{49}$ & miR-16; miR-34a; miR-34b; miR-145; miR-188-5p; miR-221; $\begin{array}{l}\text { let-7e; miR-10a; miR-17; miR-19b; miR-99a; } \\
\text { miR-601; miR-663 }\end{array}$ & miR-100; miR-152; miR-181a; miR-196a \\
\hline Blood $^{50}$ & let-7f; miR-16; miR-17-3p; miR-17-5p; miR-19a; miR-20a; & miR-143 \\
& miR-20b; miR-21; miR-24; miR-27a; miR-29a; miR-29c; & miR-125a \\
\hline miR-222 & let-7g; miR-16; miR-20a; miR-21; miR-29c & - \\
\hline Human umbilical vein & miR-17-5p; miR-19a; miR-19b; miR-20a; miR-21; miR-27b; & \\
endothelial cells ${ }^{52}$ & miR-29a; miR-29c; miR-126; miR-221; miR-222 &
\end{tabular}


in non-small cell lung cancer cell lines, have found that Drosha and Dicer were expressed at higher levels in radioresistance but not in sensitive cell lines. The downregulation of either Dicer or Drosha had no effect on the sensitivity of cells to irradiation. In other words, knockdown of these proteins separately did not alter the number of apoptotic cells in non-small cell lung cancer cell lines. This disparity might probably be associated with cell types, the degree of knockdown by small interfering RNAs, or the doses of IR used, which were different in the two studies.

In addition, Francia et al. have shown that reduction of Drosha or Dicer leads to decline in the number of cells with foci related with DNA damage response (DDR) at the injury site, but that reduction did not depend on microRNAs (the process is related to damage-site-specific sequence of RNAs managed by Dicer and Drosha).

MicroRNA has to do with modulating the expression of several post-transcriptional targets in the DDR pathway. ${ }^{54,55}$ Lal et al. ${ }^{56}$ have found that microRNA-24 is upregulated through post-mitotic differentiation of hematopoietic cell lines and controls the histone variant H2AX, a protein that has a role in the DSBs response. MicroRNA-24 downregulates the expression of H2AX and represses DNA repair. Thus, there is reduced cell capability to repair DNA DSBs. When DNA DSBs appear, microRNA-24 decreases its genomic stability and DNA damage repair capacity by regulating H2AX expression. Likewise, after DNA injury, microRNA-24-mediated downregulation of $\mathrm{H} 2 \mathrm{AX}$ increases cell death. DNA DSBs repair was promoted by suppressing microRNA-24 expression and decreased cell sensitivity to DDR. ${ }^{57} \mathrm{Hu}$ et al..$^{58}$ have demonstrated that microRNA-421 controls the ataxia-telangiectasia mutated (ATM) gene. ATM is a protein that plays a central role in the maintenance of genomic integrity by activating cell cycle checkpoints and supporting repair of DNA DSBs. MicroRNA-421 suppresses ATM expression; ectopic expression of microRNA-421 resulted in S-phase cell cycle checkpoint changes and an increased sensitivity to IR. Equally, the N-myc oncogene acts as a transcription factor on the microRNA-421 promoter region to upregulate microRNA-421 expression. As a result, finding a linear signaling pathway (microRNA-421/N-Myc/ATM) could contribute to determine a role in regulating DNA synthesis in cell cycle and in promoting tumor radiosensitivity.

Other microRNAs were also related to regulatory mechanism DNA damage repair or radiosensitivity. MicroRNA-101 was associated with DNA-dependent protein kinase catalytic subunit (DNA-PKcs) and ATM to sensitize neoplasms to radioation; 59,60 microRNA-210 and miR-373 are overexpressed in hypoxic cells and regulate the expression of various aspects in DNA damage repair pathways; ${ }^{61,62}$ microRNA-125b, microRNA-504, and microRNA-33 were correlated to p53 (one major factor in DNA-damage checkpoint activation) ${ }^{63,64}$ microRNA-421 downregulation of ATM leading to clinical manifest tumor radiosensitivity in head and neck squamous cell carcinoma ${ }^{65}$ microRNA-7 increases radiosensitivity of human tumor cells with activated epidermal growth factor receptor (EGFR) associated signaling: ${ }^{66}$ microRNA-221 and microRNA-222 control radiation sensitivity by controlling the PTEN/Akt pathway; ${ }^{67}$ microRNAs $(-155,-20$ a, -25 , and $-15 a$ ) are involved in the regulation of IR-induced premature senescence; ${ }^{68}$ lin28-let7 modulates radiosensitivity of human cancer cells with activation of K-Ras. ${ }^{69}$

In conclusion, it is not very clear if the global mechanism of microRNA disturbs sensitivity to radiation, but it is evidence that cellular radiosensitivity could indeed be influenced by microRNAs. The regulatory mechanisms of microRNA in the DNA injury repair process, if completely clarified, could offer new understanding regarding cancer radiosensitivity.

\section{Conclusion}

The observation that non-coding regions of the genome play an important role in regulating molecules that might control essential cellular functions is one of the most significant innovations in current oncology. This finding has supported insight into the mechanisms of cancer development, recognized possible biomarkers, and created possibilities for new therapies. The effort of understanding microRNA biology and converting those findings to clinical practice is just beginning. There have been several reports recording the alteration in microRNA levels upon IR from diverse cell types and the particular role of many microRNAs on cell radiosensitivity. There is evidence that microRNAs are important players in the compound response to radiation. Hence, continued research on all fronts might be of equal importance to the eventual clinical purpose of microRNA as a new class of radiosensitizing agents.

\section{ResUmo}

MicroRNAs, câncer e radiação ionizante: em que ponto estamos?

O objetivo do presente estudo é descrever a biogênese do microRNA, suas relações na carcinogênese e a correlação 
do microRNA com a radiação ionizante (RI), com enfoque na radiorresponsividade. Observou-se que a biogênese do microRNA está bem estabelecida e envolve diversas clivagens enzimáticas que resultam na produção do microRNA maduro. Os microRNAs estão envolvidos na carcinogênese. Sua interação está relacionada às alterações genéticas e epigenéticas, associadas à ativação de proto-oncogenes ou à inativação de genes supressores de tumor. Vários estudos demonstraram que os níveis de expressão de alguns microRNAs variam significativamente após a irradiação. Há evidências de que os microRNAs podem influenciar a resposta celular após a RI. Além disso, os microRNAs estão relacionados à modulação da expressão de vários alvos de pós-transcrição das vias de resposta aos danos no DNA e o do mecanismo de regulação de reparação de danos do DNA. Estudos futuros podem elucidar uma possível utilização clínica dos microRNAs como uma nova classe de agentes radiossensíveis.

Palavras-chave: microRNAs, neoplasias, radioterapia de alta energia.

\section{References}

1. Lewis BP, Burge CB, Bartel DP. Conserved seed pairing, often flanked by adenosines, indicates that thousands of human genes are microRNA targets. Cell. 2005; 120(1):15-20

2. Calin GA, Sevignani C, Dumitru CD, Hyslop T, Noch E, Yendamuri S, et al. Human microRNA genes are frequently located at fragile sites and genomic regions involved in cancers. Proc Natl Acad Sci USA. 2004; 101(9):2999-3004.

3. Fabbri M, Ivan $M$, Cimmino A, Negrini $M$, Calin GA. Regulatory mechanisms of microRNAs involvement in cancer. Expert Opin Biol Ther. 2007; 7(7):1009-19.

4. Li L, Story M, Legerski RJ. Cellular responses to ionizing radiation damage. Int J Radiat Oncol Biol Phys. 2001; 49(4):1157-62.

5. Perron MP, Provost P. Protein interactions and complexes in human microRNA biogenesis and function. Front Biosci. 2008; 13:2537-47.

6. 6. Cullen BR. Transcription and processing of human microRNA precursors. Mol Cell. 2004; 16(6):861-5

7. Han J, Lee Y, Yeom KH, Kim YK, Jin H, Kim VN. The Drosha-DGCR8 complex in primary microRNA processing. Genes Dev. 2004; 18(24):3016-27.

8. Lee Y, Ahn C, Han J, Choi H, Kim J, Yim J, et al. The nuclear RNase III Drosha initiates microRNA processing. Nature. 2003; 425(6956):415-9.

9. Chendrimada TP, Gregory RI, Kumaraswamy E, Norman J, Cooch N, Nishikura K, et al. TRBP recruits the Dicer complex to Ago 2 for microRNA processing and gene silencing. Nature. 2005; 436(7051):740-4.

10. Lee Y, Hur I, Park SY, Kim YK, Suh MR, Kim VN. The role of PACT in the RNA silencing pathway. EMBO J. 2006; 25(3):522-32.

11. Kwak PB, Iwasaki S, Tomari Y. The microRNA pathway and cancer. Cancer Sci. 2010; 101(11):2309-15.

12. Kim VN. MicroRNA biogenesis: coordinated cropping and dicing. Nat Rev Mol Cell Biol. 2005; 6(5):376-85.

13. Graves P, Zeng Y. Biogenesis of mammalian microRNAs: a global view. Genomics Proteomics Bioinformatics. 2012; 10(5):239-45.

14. Sun BK, Tsao H. Small RNAs in development and disease. J Am Acad Dermatol. 2008; 59(5):725-37.

15. Zhang W, Dahlberg JE, Tam W. MicroRNAs in tumorigenesis: a primer. Am J Pathol. 2007; 171(3):728-38.

16. Fabbri M, Ivan M, Cimmino A, Negrini M, Calin GA. Regulatory mechanisms of microRNAs involvement in cancer. Expert Opin Biol Ther. 2007; 7(7):1009-19.

17. Johnson SM, Grosshans H, Shingara J, Byrom M, Jarvis R, Cheng A, et al. RAS is regulated by the let-7 microRNA family. Cell. 2005; 120(5):635-47.
18. Garzon R, Calin GA, Croce CM. MicroRNAs in cancer. Annu Rev Med. 2009; 60:167-79.

19. Calin GA, Dumitru CD, Shimizu M, Bichi R, Zupo S, Noch E, et al. Frequent deletions and down-regulation of micro-RNA genes miR15 and miR16 at $13 q 14$ in chronic lymphocytic leukemia. Proc Natl Acad Sci USA. 2002; 99(24):15524-9.

20. Abba M, Mudduluru G, Allgayer H. MicroRNAs in cancer: small molecules, big chances. Anticancer Agents Med Chem. 2012; 12(7):733-43.

21. Lee ST, Chu K, Oh HJ, Im WS, Lim JY, Kim SK, et al. Let-7 microRNA inhibits the proliferation of human glioblastoma cells. J Neurooncol. 2011; 102(1):19-24.

22. Dong Q, Meng P, Wang T, Qin W, Qin W, Wang F, et al. MicroRNA let-7a inhibits proliferation of human prostate cancer cells in vitro and in vivo by targeting E2F2 and CCND2. PLoS One. 2010; 5(4):e10147.

23. Kumar MS, Erkeland SJ, Pester RE, Chen CY, Ebert MS, Sharp PA, et al. Suppression of non-small cell lung tumor development by the let-7 microRNA family. Proc Natl Acad Sci U S A. 2008; 105(10):3903-8.

24. Chow TF, Mankaruos M, Scorilas A, Youssef Y, Girgis A, Mossad S, et al. The miR-17-92 cluster is over expressed in and has an oncogenic effect on renal cell carcinoma. J Urol. 2010; 183(2):743-51.

25. Hayashita Y, Osada H, Tatematsu Y, Yamada H, Yanagisawa K, Tomida S, et al. A polycistronic microRNA cluster, miR-17-92, is overexpressed in human lung cancers and enhances cell proliferation. Cancer Res. 2005; 65(21):9628-32.

26. Calin GA, Sevignani C, Dumitru CD, Hyslop T, Noch E, Yendamuri S, et al. Human microRNA genes are frequently located at fragile sites and genomic regions involved in cancers. Proc Natl Acad Sci U S A. 2004; 101(9):2999-3004.

27. Zhang L, Huang J, Yang N, Greshock J, Megraw MS, Giannakakis A, et al. MicroRNAs exhibit high frequency genomic alterations in human cancer. Proc Natl Acad Sci U S A. 2006; 103(24):9136-41.

28. Raveche ES, Salerno E, Scaglione BJ, Manohar V, Abbasi F, Lin YC, et al. Abnormal microRNA-16 locus with synteny to human 13q14 linked to CLL in NZB mice. Blood. 2007; 109(12):5079-86.

29. Toyota M, Suzuki H, Sasaki Y, Maruyama R, Imai K, Shinomura Y, et al. Epigenetic silencing of microRNA-34b/c and B-cell translocation gene 4 is associated with $\mathrm{CpG}$ island methylation in colorectal cancer. Cancer Res. 2008; 68(11):4123-32

30. Scott GK, Mattie MD, Berger CE, Benz SC, Benz CC. Rapid alteration of microRNA levels by histone deacetylase inhibition. Cancer Res. 2006; 66(3):1277-81.

31. Rhodes LV, Nitschke AM, Segar HC, Martin EC, Driver JL, Elliott S, et al. The histone deacetylase inhibitor trichostatin A alters microRNA expression profiles in apoptosis-resistant breast cancer cells. Oncol Rep. 2012; 27(1):10-6.

32. Wang Y, Medvid R, Melton C, Jaenisch R, Blelloch R. DGCR8 is essential for microRNA biogenesis and silencing of embryonic stem cell self-renewal. Nat Genet. 2007; 39(3):380-5.

33. Kumar MS, Pester RE, Chen CY, Lane K, Chin C, Lu J, et al. Dicer1 functions as a haploinsufficient tumor suppressor. Genes Dev. 2009; 23(23):2700-4.

34. Karube Y, Tanaka H, Osada H, Tomida S, Tatematsu Y, Yanagisawa K, et al. Reduced expression of Dicer associated with poor prognosis in lung cancer patients. Cancer Sci. 2005; 96(2):111-5.

35. Grelier G, Voirin N, Ay AS, Cox DG, Chabaud S, Treilleux I, et al. Prognostic value of Dicer expression in human breast cancers and association with the mesenchymal phenotype. Br J Cancer. 2009; 101(4):673-83.

36. Lin RJ, Lin YC, Chen J, Kuo HH, Chen YY, Diccianni MB, et al. MicroRNA signature and expression of Dicer and Drosha can predict prognosis and delineate risk groups in neuroblastoma. Cancer Res. 2010; 70(20):7841-50.

37. Guo X, Liao Q, Chen P, Li X, Xiong W, Ma J, et al. The microRNA-processing enzymes: Drosha and Dicer can predict prognosis of nasopharyngeal carcinoma. J Cancer Res Clin Oncol. 2012; 138(1):49-56.

38. Martello G, Rosato A, Ferrari F, Manfrin A, Cordenonsi M, Dupont S, et al. A MicroRNA targeting dicer for metastasis control. Cell. 2010; 141(7):1195-207.

39. Piovan C, Palmieri D, Di Leva G, Braccioli L, Casalini P, Nuovo G, et al. Oncosuppressive role of p53-induced miR-205 in triple negative breast cancer. Mol Oncol. 2012; 6(4):458-72.

40. Mott JL, Kurita S, Cazanave SC, Bronk SF, Werneburg NW, Fernandez-Zapico ME. Transcriptional suppression of mir-29b-1/mir-29a promoter by c-Myc, hedgehog, and NF-kappaB. J Cell Biochem. 2010; 110(5):1155-64.

41. Burk U, Schubert J, Wellner U, Schmalhofer O, Vincan E, Spaderna S, et al. A reciprocal repression between ZEB1 and members of the miR-200 family promotes EMT and invasion in cancer cells. EMBO Rep. 2008; 9(6):582-9.

42. Engels BM, Hutvagner G. Principles and effects of microRNA-mediated post-transcriptional gene regulation. Oncogene. 2006; 25(46):6163-9. 
43. Deng S, Calin GA, Croce CM, Coukos G, Zhang L. Mechanisms of microRNA deregulation in human cancer. Cell Cycle. 2008; 7(17):2643-6.

44. Bussing I, Slack FJ, Grosshans H. Let-7 microRNAs in development, stem cells and cancer. Trends Mol Med. 2008; 14(9):400-9.

45. Johnson SM, Grosshans H, Shingara J, Byrom M, Jarvis R, Cheng A, et al. RAS is regulated by the let-7 microRNA family. Cell. 2005; 120(5):635-47.

46. Dent P, Yacoub A, Fisher PB, Hagan MP, Grant S. MAPK pathways in radiation responses. Oncogene. 2003; 22(37):5885-96.

47. Simone NL, Soule BP, Ly D, Saleh AD, Savage JE, Degraff W, et al. Ionizing radiation-induced oxidative stress alters miRNA expression. PLoS One. 2009; 4(7):e6377.

48. Tarasov V, Jung P, Verdoodt B, Lodygin D, Epanchintsev A, Menssen A, et al. Differential regulation of microRNAs by $\mathrm{p} 53$ revealed by massively parallel sequencing: miR-34a is a p53 target that induces apoptosis and G1-arrest. Cell Cycle. 2007; 6(13):1586-93.

49. Koturbash I, Zemp F, Kolb B, Kovalchuk O. Sex-specific radiation-induced microRNAome responses in the hippocampus, cerebellum and frontal cortex in a mouse model. Mutat Res. 2011; 722(2):114-8.

50. Dickey JS, Zemp FJ, Martin OA, Kovalchuk O. The role of miRNA in the direct and indirect effects of ionizing radiation. Radiat Environ Biophys. 2011; 50(4):491-9

51. Kraemer A, Anastasov N, Angermeier M, Winkler K, Atkinson MJ, Moertl S. MicroRNA-mediated processes are essential for the cellular radiation response. Radiat Res. 2011; 176(5):575-86.

52. Surova O, Akbar NS, Zhivotovsky B. Knock-down of core proteins regulating microRNA biogenesis has no effect on sensitivity of lung cancer cells to ionizing radiation. PLoS One. 2012; 7(3):e33134.

53. Francia S, Michelini F, Saxena A, Tang D, de Hoon M, Anelli V, et al. Sitespecific DICER and DROSHA RNA products control the DNA-damage response. Nature. 2012; 488(7410):231-5

54. Landau DA, Slack FJ. MicroRNAs in mutagenesis, genomic instability, and DNA repair. Semin Oncol. 2011; 38(6):743-51.

55. $\mathrm{Hu} \mathrm{H}$, Gatti RA. MicroRNAs: new players in the DNA damage response. J Mol Cell Biol. 2011; 3(3):151-8.

56. Lal A, Pan Y, Navarro F, Dykxhoorn DM, Moreau L, Meire E, et al. miR-24 mediated downregulation of $\mathrm{H} 2 \mathrm{AX}$ suppresses DNA repair in terminally differentiated blood cells. Nat Struct Mol Biol. 2009; 16(5):492-8.

57. Srivastava N, Manvati S, Srivastava A, Pal R, Kalaiarasan P, Chattopadhyay $\mathrm{S}$, et al. miR-24-2 controls H2AFX expression regardless of gene copy number alteration and induces apoptosis by targeting antiapoptotic gene BCL-2: a potential for therapeutic intervention. Breast Cancer Res. 2011; 13(2):R39.

58. Hu H, Du L, Nagabayashi G, Seeger RC, Gatti RA. ATM is down-regulated by N-Myc-regulated microRNA-421. Proc Natl Acad Sci U S A. 2010; 107(4):1506-11.

59. Yan D, Ng WL, Zhang X, Wang P, Zhang Z, Mo YY, et al. Targeting DNAPKcs and ATM with miR-101 sensitizes tumors to radiation. PLoS One. 2010; 5(7):e11397.

60. Chen S, Wang H, Ng WL, Curran WJ, Wang Y. Radiosensitizing effects of ectopic miR-101 on non-small-cell lung cancer cells depend on the endogenous miR-101 level. Int J Radiat Oncol Biol Phys. 2011; 81(5):1524-9.

61. Crosby ME, Kulshreshtha R, Ivan M, Glazer PM. MicroRNA regulation of DNA repair gene expression in hypoxic stress. Cancer Res. 2009; 69(3):1221-9.

62. Arai N, Kagawa W, Saito K, Shingu Y, Mikawa T, Kurumizaka H, et al. Vital roles of the second DNA-binding site of Rad52 protein in yeast homologous recombination. J Biol Chem. 2011; 286(20):17607-17.

63. Hermeking H. MicroRNAs in the 553 network: micromanagement of tumour suppression. Nat Rev Cancer. 2012; 12(9):613-26.

64. Medema RH, Mac冈rek L. Checkpoint control and cancer. Oncogene. 2012; 31(21):2601-13.

65. Mansour WY, Bogdanova NV, Kasten-Pisula U, Rieckmann T, Köcher S, Borgmann K, et al. Aberrant overexpression of miR-421 downregulates ATM and leads to a pronounced DSB repair defect and clinical hypersensitivity in SKX squamous cell carcinoma. Radiother Oncol. 2013; 106(1):147-54.

66. Lee KM, Choi EJ, Kim IA. microRNA-7 increases radiosensitivity of human cancer cells with activated EGFR-associated signaling. Radiother Oncol. 2011; 101(1):171-6

67. Zhang C, Kang C, Wang P, Cao Y, Lv Z, Yu S, et al. MicroRNA-221 and -222 regulate radiation sensitivity by targeting the PTEN pathway. Int J Radiat Oncol Biol Phys. 2011; 80(1):240-8.

68. Wang Y, Scheiber MN, Neumann C, Calin GA, Zhou D. MicroRNA regulation of ionizing radiation-induced premature senescence. Int J Radiat Oncol Biol Phys. 2011; 81(3):839-48

69. Oh JS, Kim JJ, Byun JY, Kim IA. Lin28-let7 modulates radiosensitivity of human cancer cells with activation of K-Ras. Int J Radiat Oncol Biol Phys. 2010; 76(1):5-8. 